\title{
ОБШЕСТВЕННЫЕ КОММУНИКАЦИИ
}

\author{
И. А. Пашинян
}

\section{МИФ КАК ИСТОЧНИК ИНФОРМАЦИОННЫХ РИСКОВ СМИ}

\begin{abstract}
Аннотация. В статье рассматривается механизм продуцирования информационных рисков СМИ в результате создания мифов. Информационные риски СМИ часто возникают как следствие, вполне позитивных процессов. Существует объективное противоречие между иелью предоставления гражданам сбалансированной информации с одной стороны, и предоставлением основным политическим силам и движениям доступа к СМИ с другой стороны. Инструменты создания мифа сами по себе несут риски

Ключевые слова: политология, информационные риски, сми, миф, общественное мнение, ложь, клевета, фальсификация, насилие, граждане.
\end{abstract}

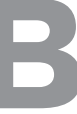
ажным источником формирования информационных рисков являются различия внутренних миров людей сформированных, в частности, на основе влияния СМИ. Различия в системах ценностей людей, в оценках ими одних и тех же фактов, ведет к тому, что между ними возникает конфликт, что в обществе формируются различные группы, которые под их влиянием принципиально иначе воспринимают один и тот же окружающий мир, что и лежит в основе возникновения информационных рисков.

Информационные риски СМИ не существуют сами по себе. Они возникают как следствие, неизбежное следствие, часто вполне позитивных процессов, в частности, процессов мифотворчества, которое является важным инструментом формирования восприятие мира мифотворчество. Миф (от греч. mythos - слово, повествование, предание) - предание лежащее в основе понимания реальности. Пока никем до конца не объясненным образом мифы разных эпох и народов строятся по сходным канонам.

Искусственная мифология не может быть создана только демагогией и ложью. На этом мифология долго не продержится. Эффективная мифология всегда основана на архаических, как правило, религиозных представлениях. Прекрасный пример - марксизм в русском варианте являлся классическим примером мифотворчества. Гениальным творцом этой мифологии был И.В.Сталин, который очень эффективно использовал свои знания механизмов действия культов.

Мифологическое мышление по своей природе дуалистично. А это значит, что так же как полюс магнита не может существовать один, без своей противоположнос- ти, также и для создания положительного образа, мифу требуется отрицательный образ, чаще всего образ врага. А это неизбежно продуцирует конфликт и информационные риски. В мифе весь мир всегда делится на добро и зло, на своих и врагов. Например, советское мышление, воспринимало заграницу как иной мир. Контакты с ним были нежелательны в принципе и требовали многих предосторожностей. Надзор за соблюдением правил безопасности был одной из важных функций Коммунистической Партии.

Подспудной особенностью мифологического мышления является совершенно специфическое отношение к слову, а отсюда, и особенная роль СМИ. В СССР существовали трудно объяснимые, с точки зрения здравого смысла, правила. Например, нельзя было упоминать в отрицательном контексте (таких как обвинительные акты) имена руководителей партии и правительства, они заменялись эвфемизмами. В одном документе, где речь шла о человеке, непочтительно высказавшемся о Сталине в траурные дни марта 1953 г., было сказано: «Об одном из руководителей партии и советского государства, недавно умершем».

Запрещение называния имени можно объяснить только традиционным запретов многих культов на упоминание того, что наделено мистической силой. Таки образом слово, а еще шире СМИ, воспринимается как магическое орудие. Отголоски вербальной магии прослеживаются во многом. Вера в силу высказанного слова глубоко укоренена в русской культуре. На слове базировалась вся советская пропаганда, которая успешно создала в стране вторую реальность. Эта вторая реальность воспринималась даже «реальнее реальной». 


\section{Право и политика - №7(151)•2012}

Другого рода магические манипуляции, были связаны с осквернением изображений вождей и государственной символики. Поэтому табуирование изображений являлось также фундаментальной составляющей советской мифологии.

Всего столетие назад внутренний мир людей формировался на основе их личного опыта, опыта общения, опыта профессиональной деятельности и путешествий. Сегодня внутренний мир человека в значительной степени формируется еще и мифами, создаваемыми средствами массовой информации. С помощью СМИ рекламируются социальные идеи, создаются удобные политические образы, навязывается массовая политическая культура, образ жизни, услуги и товары. Телевидение, радио, печать, Интернет, реклама стали основными источниками информации, формирующими внутренний мир человека.

Для понимания природы информационных рисков СМИ особенно важны даже не различия в представляемых СМИ системах фактов, а модели их интерпретации. Психологи давно установили, что разные люди живут в разной среде. Разные СМИ, в зависимости от своих целей, по-разному формируют информационную среду ${ }^{1}$. В мифотворчестве особо выделяется роль телевидения. Телевидению доступны специальные приемы, которые другие СМИ не могут полностью и одновременно использовать.

В качестве примера рассмотрим приемы, используемые в мультфильмах. Это, прежде всего, яркий видеоряд позволяющий образовать определенное световое ощущение. Чем оно сильнее, тем сильнее к нему приковывается и внимание, а за вниманием и психика. Очень эффективны и звуковые эффекты которые используются для создания определенного ощущения, и чем оно сильнее, тем сильнее к нему приковывается и внимание, а за вниманием и психика. Новизна и необычность также привлекает к экрану, потому что по закону движения и устремления психических процессов монотонность вызывает отвращение. Особо действенным средством является показ крупным планом лица героя. Показ крупным планом является фактором гипнотизации, потому что, смотря на человеческое лицо, телезритель сразу проникается к нему симпатией или отвращением и невольно остановит свое внимание на телеэкране. Современное телевидение использует все известные психологической науке эффекты: быстрой вспышки; громкого звука, после которых резкое возбуждение

\footnotetext{
${ }^{1}$ Практически все СМИ кому-то принадлежат, следовательно, исполняют их волю, лоббируют их интересы. Хозяин никогда не допустит высказываний, приносящих ему какой-то вред. То, что восхваляется СМИ, скорее всего, полезно его хозяину и в лучшем случае бесполезно потребителю информации.
}

нервной системы быстро сменяется торможением; прерывание на самом трагическом месте, которое побуждает ребёнка с нетерпением ждать следующей серии. Кстати последний прием делает телезрителя заинтересованным и, вследствие этого, открытым для нового сеанса внушения. В последнее время все активнее используются спецэффекты, в частности компьютерные спецэффекты, которые мгновенно вторгаются в психику, вызывая ее частичное разрушение с целью внушения или изменения психических процессов

В отличие от других видов видео культуры телевидения представляет собой часть домашней обстановки (в этом оно гораздо ближе радио, чем кино). Этот факт сам по себе весьма амбивалентен и по-разному оценивается с разных исследовательских позиций. Сильный эффект телевидения, кроме его собственно содержательной стороны, - это сам факт его существования, его способность свести граждан до уровня пассивных зрителей в течение большей части их жизни. Телевидение сводит до минимума личностные взаимодействия внутри семьи и сообщества ${ }^{2}$. Такое «все присутствие» телевидения в повседневности приводит к тому, что его звуковой ряд доминирует над каналами коммуникации. Интересен, в связи с этим, такой парадокс: чаще всего отношение с телевидением - это отношение слушателя, а не зрителя.

Телевидение может привести к заметным отличиям восприятия реальности разными социальными группами. Например, современные дети живут в информационном пространстве, отличающемся от того, в котором жили дети их возраста всего сорок лет назад. Дети из-за отсутствия у них полного осознания границ реальности, все события, которые происходят перед их глазами, воспринимают как настоящие. Они по-другому относятся частности к насилию: оно не вызывают у них чувств страха или отвращения․ Телевидением формируется другая мифологическая реальность. В наиболее популярных телевизионных программах на каждый час вещания приходится в среднем около девяти актов физической и восьми актов вербальной агрессии ${ }^{4}$. Поэтому ребенок, проводящий у телевизора, например, всего лишь два часа, видит за день в среднем свыше семнадцати актов агрессии.

Считается, что сцены насилия на экране и фильмы ужасов делают человека более агрессивными и жестокими 5 . Но до сих пор идет дискуссия о том, оказывают ли на самом деле военные действия и сцены насилия, мер-

\footnotetext{
2 Паренти М. Media. - М., 1992. - 11-12 стр.

${ }^{3}$ Мельник Г.C. Mass-media: психологические процессы и эффекты. - СПб, 1996. - 196 с.

${ }^{4}$ Бэрон Р. Ричардсон Д. Агрессия. - СПб.: Питер, 1997. - 107 с.

${ }_{5}^{5}$ Бэрон Р. Ричардсон Д. Агрессия. - СПб.: Питер, 1997. - 336 с.
} 
цающие на экране, отрицательное воздействие на детей. Одни ученые считают ${ }^{6}$, что в видеофильмах ребенок бессознательно реализует определенные свои потребности, чему во многом способствуют образы героев фильмов. Поэтому чрезмерное увлечение видео и телевидением возникает только у тех детей, которые испытывают затруднения в адаптации к действительности.

Важное место среди инструментов мифотворчества занимают ложь и фальсификации. Но сама ложь уже себе в себе риски. Обычно под словом «Ложь» понимается утверждение, не соответствующее истине. В политике, как и в журналистике, слово «правда» часто означает любое утверждение, лживость которого не может быть доказана, прямо. Ложь, дезинформация и фальсификация являются наиболее распространенными способами и приемами манипулирование сознанием. Для понимания рисков СМИ продуцируемых ложью в России важно, что «ложный» в русском языке означает не только не истинный, а еще и неправедный поступок.

Ложь в СМИ имеет разные формы. Иногда это неприкрытая ложь - утверждение, ложность которого очевидна не только тому, кто его высказывает, но и всем заинтересованным лицам. Кстати еще Геббельс доказал, что такая ложь может быть достаточно эффективна при условии необычности и частого повторения. Хотя задолго до него Наполеон говорил, что есть одна заслуживающая внимания фигура риторики - это повторение.

Неприкрытая ложь хотя и встречается в СМИ, но редко, так как преследуется по закону. Следует различать понятие лжи в общепринятом смысле и в юридических смыслах. Право использует два базовых понятия: клевета и диффамация. Клевета это - порочащая кого-нибудь ложь. ${ }^{8}$ Клевета и клеветать - юридические подкатегории диффамации 9 .

СМИ редко использует прямую ложь, так как это и дорого, и опасно ${ }^{10}$. В разных вариантах повторяется такой афоризм: «Какой смысл лгать, если того же результата можно добиться, тщательно дозируя правду?». Если иметь в виду классическую фору лжи, а точнее,

\footnotetext{
${ }^{6}$ Бюттер К. Жить с агрессивными детьми. - М.: Просвещение, 1997. - 122 c.

${ }^{7}$ Толковый словарь Ожегова - http://www.ozhegov.ru/ slovo/21517.html

${ }^{8}$ Толковый словарь Ожегова - http://www.ozhegov.ru/ slovo/17933.html

${ }^{9}$ Агапов А. Информационное законодательство России. М., 1993.

${ }^{10} \mathrm{O}$ негативном влиянии лжи на человека было известно ещё в глубокой древности. Девятая христианская заповедь гласит: «Не послушествуй на друга своего свидетельства ложна!», - т.е. она запрещает верующему доносы, сплетни, неискренность и обман по отношению к другому человеку.
}

юридически определенную фору лжи, то это так. Чаще используются микширование лжи с правдой и недоговорки. Микширование лжи и правды. Этот метод был отработан уже в ведомстве Геббельса ${ }^{11}$. Так, фашисты ввели прием подстраховки ложных сообщений правдивыми, даже очень для них неприятными.

Широко используются и недоговорки - ситуации, в которой СМИ сообщают ряд фактов, но скрывают самый главный из них, позволяя аудитории прийти к ошибочному выводу. Недоговорка является частным случаем введения в заблуждение. Высказывание, вводящее в заблуждение, которое не содержит явной лжи, но, тем не менее, его целью является попытка заставить поверить в истинность того, что истиной не является. Оно строится таким образом, что все факты в нём истинны, однако подобраны таким образом и в такой последовательности, что подталкивают слушающего к неверному выводу.

Специфика политического сознания состоит в том, что верифицировать что-либо опытными средствами чрезвычайно сложно. Информации для такой верификации, как правило, недостаточно. И, кроме того, существует определенная ригидность стереотипа, препятствующая сопоставлению различных, подчас прямо противоположных информационных вариантов. В результате, политико-мифологическое сознание просто «тяготеет» к определенному стереотипу, четко выраженному и эмоционально окрашенному.

Иногда возможности для сопоставления даются, но они выбраны так, что ведут к заведомо ложному выводу. Пример: одна московская радиостанция, после многократного повторения сообщения о сложностях с бензином в Петербурге задала своим слушателям вопpoc: «Нужно ли поставлять горючее в Югославию?» При этом не было никакого упоминания мнений профессиональных экспертов о причинах сложностей с горючим и информации о потере экспортных доходов России в случае срыва поставок в Югославию. В итоге $75 \%$ людей, позвонивших на станцию, дали отрицательный ответ. В этом же ряду стоит и преувеличение, которое возникает, если качественно высказывание является истинным, но приведённые количественные характеристики приукрашены, и действительности не соответствуют ${ }^{12}$.

Разновидностью лжи в СМИ является изменение смысла слов и понятий. Оно заключается в «конструирование» сообщения из обрывков высказывания или видеоряда, посредством которого меняется контекст, т.е. сказанные слова приобретают совершенно иной смысл. Отобранные «крупицы» сообщения вроде бы не являются ложью, но «целое» может не иметь ничего общего с

\footnotetext{
${ }^{11} \mathrm{http} / / /$ ru.wikipedia.org/wiki/Геббельс

${ }^{12}$ Википедия - http://ru.wikipedia.org/wiki/Ложь
} 
действительностью. В СМИ активно используются такие понятия как «принуждение к миру», «друзья страны», а на самом деле - блок стран-агрессоров и т.д.

Современная пропаганда чаще использует не прямую ложь, которую легко опровергнуть, а фальсификацию. Прямая ложь применяется только как тест для определения порога чувствительности людей с целью дальнейшей корректировки допустимого уровня манипуляции ими. Фальсификация, в отличие ото лжи, не содержит фактов, противоречащих истине, а сообщает верные факты, но вне контекста, так, что они приобретают иной смысл. Непрямая ложь заменяется манипулированием, которое обычно эффективнее прямой лжи ${ }^{13}$.

Фальсификация ${ }^{14}$ - это утверждение, высказываемое человеком, не уверенным в его истинности. Хотя такое утверждение и может выглядеть правдоподобным (а иногда даже и оказываться истинным), оно не основано на фактах; оно либо выдумано, либо не соответствует действительности.

Еще один активно используемый СМИ метод фальсификации - ложные аналогии. Метод основан на склонности человека мыслить аналогиями, строить в своем мышлении в псевдологические последовательности. Привычным для большинства людей стилем мышления является тот стиль, который использует логические связки «причина - следствие». Эти связки кажутся полностью доступными контролю сознания и соответствуют сфере «здравого смысла». Связку «конкретная причина - конкретное следствие», которая имела место когда-либо, люди склонны экстраполировать и на другие объекты, не имеющие никакого отношения к первоначальным. Эта психологическая особенность активно используется пропагандистами.
Например, такое: «Британская империя распалась - значит, и СССР должен был распасться!». И никаких обоснований подобия, почему сравнивают с Британской империей, а не с Китаем и не с США? Или и они должны распасться и именно сегодня? На использовании ложных аналогий строится пропагандистская техника создания Ассоциативных связей.

Проведенный выше обзор механизмов возникновения информационных рисков СМИ в результате мифотворчества позволяет сделать ряд выводов:

1. Информационные риски СМИ часто возникают как следствие, вполне позитивных процессов, в частности, процессов мифотворчества. Источником информационных рисков СМИ являются различия внутренних миров людей сформированных, в частности, на основе влияния СМИ. Эти различия могут приводить, и часто приводят к конфликтам.

2. Эффективная мифология всегда основана на архаических, как правило, религиозных представлениях. Ее создание предполагает использование таких инструментов как ложь и фальсификация, которые сами по себе несут в себе риски.

3. Существует объективное противоречие между целью предоставления гражданам сбалансированной информации с одной стороны, и предоставлением основным политическим силам и движениям доступа к СМИ с другой стороны. Следствием свободы слова могут быть и информационные риски СМИ.

4. Объективная противоречивость различных целей деятельности СМИ заметно усложняет задачу определения допустимого уровня свободы слова, которая не провоцировала бы превышения допустимых уровней информационных рисков СМИ.

\footnotetext{
${ }^{13}$ Кара-Мурза С.Г. Манипуляция сознанием. М., 2001.

14 Лат. Falsificare подделывать - подделывание чего-либо, искажение, подмена чего-либо подлинного ложным, мнимым. Так же изменение с корыстной целью качества предметов сбыта в сторону ухудшения при сохранении внешнего вида.
} 


\section{Библиография}

1. Агапов А. Информационное законодательство России. М., 1993.

2. Бэрон Р. Ричардсон Д. Агрессия. СПб., 1997.

3. Кара-Мурза С.Г. Манипуляция сознанием. М., 2001.

4. Мельник Г.С. Mass-media: психологические процессы и эффекты. СП.б, 1996.

5. Паренти М. Media. М., 1992.

6. Толковый словарь Ожегова - http://www.ozhegov.ru/slovo/21517.html

7. Толковый словарь Ожегова - http://www.ozhegov.ru/slovo/17933.html

\section{References (transliteration)}

1. Agapov A. Informatsionnoe zakonodatel'stvo Rossii. M., 1993.

2. Beron R. Richardson D. Agressiya. SPb., 1997.

3. Kara-Murza S.G. Manipulyatsiya soznaniem. M., 2001.

4. Mel'nik G.S. Mass-media: psikhologicheskie protsessy i effekty. SP.b, 1996.

5. Parenti M. Media. M., 1992.

6. Tolkovyy slovar' Ozhegova - http://www.ozhegov.ru/slovo/21517.html 